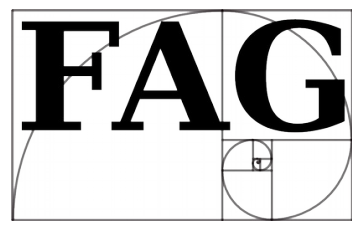

Filozoficzne Aspekty Genezy - 2014, t. 11

Philosophical Aspects of Origin

s. $243-259$

http://www.nauka-a-religia.uz.zgora.pl/images/FAG/2014.t.11/art.11.pdf

Nathan Aviezer

\title{
Kabała, nauka i stworzenie Wszechświata *
}

W ostatnich latach wielu naukowców o inklinacji religijnej, w tym ja, pisało obszernie o zgodności pomiędzy odkryciami współczesnej nauki a Torą ${ }^{* *}$ zgodności dotyczącej opisu Stworzenia. ${ }^{1} \mathrm{~W}$ szczególności kosmologiczna teoria Wielkiego Wybuchu dostarcza wyjaśnień naukowych ${ }^{23}$ dla każdego słowa

*Nathan Aviezer, „Kabbalah, Science and the Creation of the Universe”, Jewish Action 2004, vol. 65, no. 1, http://ou.org.s3.amazonaws.com/publications/ja/5765/5765fall/KABBALAH.PDF (22.03.2015). Za zgodą Autora oraz Redakcji z języka angielskiego przełożyła: Dorota BRYLLA.

Translated and reprinted with permission from Jewish Action, Fall 2004.

** (Przyp. thum.) W sensie węższym — i takie ma tu na myśli autor — tj. Pięcioksięgu Mojżeszowego, a więc pierwszych pięciu ksiąg Tanachu żydów i Starego Testamentu chrześcijan (w szerszym znaczeniu Torą określany bywa cały Tanach, a w najszerszym — całość nauki judaizmu: doktryna tak pisemna, jak i ustna).

${ }^{1}$ Nathan Aviezer, In the Beginning: Biblical Creation and Science, KTAV Publishing House, Inc., New Jersey 1990; Nathan Aviezer, Fossils and Faith: Understanding Torah and Science, KTAV Publishing House, Inc., New Jersey 2002); Gerald Schroeder, Genesis and the Big Bang: The Discovery of Harmony Between Modern Science and the Bible, Bantam, New York 1990; Gerald Schroeder, The Science of God: The Convergence of Scientific and Biblical Wisdom, Free Press, New York 1997; Yehudah Levi, Facing Current Challenges: Essays on Judaism, Hemed Books, Inc., New York, 1998; Yehudah Levi, Science in Torah: The Scientific Knowledge of the Talmudic Sages, Feldheim, New York 2004.

${ }^{2}$ Por. dla przykładu Aviezer, In the Beginning..., rozdz. 1.

${ }^{3}$ Stwierdzenie to odnosi się do słów Tory mających treść fizyczna, przy czym w Torze, w pierwszym rozdziale Bereszit, występują także słowa, które posiadają wyłącznie treść ducho$w a$, jak ,a duch Boży unosił się nad powierzchnią wód” (1:2) [cyt. za: Bereszit/Genesis, przeł. Izaak Cylkow, Kraków 1895 (przyp. tłum.)]. Oczywiście nauka nie potrafi nam nic powiedzieć o znaczeniu tego wersetu Tory. 
i zdania, które pojawiają się w pierwszych pięciu wersetach Bereszit * — opisie Pierwszego Dnia Stworzenia. Zważywszy na te niezwykłe związki pomiędzy Torą i nauką, kuszące jest zbadanie innego tradycyjnego źródła, które podejmuje temat stworzenia Wszechświata, mianowicie kabały.

Kabała ${ }^{* *}$ przedstawia opis Stworzenia bardzo różniący się od opisu pojawiającego się w pierwszym rozdziale Bereszit. Nie stanowi to jednak o sprzeczności pomiędzy tymi dwoma ujęciami tego samego zdarzenia. Owe dwie wersje skupiają się raczej na innych aspektach. Opis Tory dotyczy rzeczywistej sekwencji zdarzeń (Dzień Pierwszy, Dzień Drugi i tak dalej), a kabała akcentuje rolę Boga w procesie Stworzenia i Jego oddziaływania z Wszechświatem.

Czy opis Stworzenia prezentowany przez kabałę może być zestawiony z odkryciami współczesnej nauki? Na to pytanie można by odpowiedzieć przecząco, wskazując, że przedmiotem rozważań kabały jest rzeczywistość duchowa, podczas gdy nauka ogranicza się do badania rzeczywistości fizycznej. Wszelako jednym z fundamentalnych założeń kabały jest, że rzeczywistość duchowa świata górnego zstępuje, przyjmując odpowiednią formę, aby stworzyć swój fizyczny odpowiednik w świecie dolnym. Dlatego też uzasadnione jest pytanie: Czy możliwe jest odnalezienie takich właściwości świata fizycznego, które można by odnieść do nauczania kabały? Jak zobaczymy, odpowiedź na to pytanie brzmi „tak”.

Na przestrzeni ostatnich kilku dekad odkryto, że Wszechświat fizyczny jest miejscem znacznie bogatszym, dziwniejszym i bardziej zdumiewającym niż można było sobie wyobrazić. To właśnie ta subtelność i złożoność świata fizycznego dostarczają ram odniesienia dla wykazywania różnych jego powiązań $\mathrm{z}$ duchowym światem kabały.

\footnotetext{
* (Przyp. tłum.) Oryginalny tytuł Księgi Rodzaju (Księgi Genesis, Pierwszej Księgi Mojżeszowej) [dosłownie z hebrajskiego — co ważne w kontekście niniejszych rozważań — „Księgi Początku"], pierwszej księgi Tory.

** (Przyp. tłum.) Najogólniej: gałąź mistycyzmu żydowskiego.
} 


\section{Kabala}

Są uczeni, którzy całe swoje życie poświęcili na studiowanie tajemnic kabały. Oczywiste jest więc, że niniejszy esej nie będzie wyczerpującą analizą tematu. Dla naszych celów wystarczające jest skoncentrowanie się na kilku podstawowych ideach.

Należy zauważyć, że istnieje kilka różnych tradycji kabały. Nasza prezentacja podążać będzie za systemem Ariego (Rawa Izaaka Lurii, XVI w. "), którego podejście do kabały zostało zapowiedziane w pismach wcześniejszych mekubalim (kabalistów). Poglądy Ariego zostały spisane przez jego najważniejszego ucznia, Rawa Chajima Witala. ${ }^{4}$

Jedną z podstawowych koncepcji kabały są sefirot. Pochodzenie tego terminu rozumiane było w przeróżny sposób: sefirot są albo „sferami”, albo sapirim wskazującymi na Boga „promieniowanie i lśnienie”, albo mesaprim ** odnoszącymi się do Boskiego kosmosu „obwieszczającego” chwałę Boga. Istota Boga nie może być poznana. O Bogu dowiadujemy się wyłącznie poprzez Jego manifestacje. Tymi głównymi manifestacjami jest dziesięć sefirot, które reprezentują Boskie emanacje lub wymiary. Idea badania [resp. zgłębiania] sefirot podejmowana jest w Sefer Jecira ${ }^{* * *} 1: 4$ :

\footnotetext{
* (Przyp. tłum.) Imię Ari to akronim słów Elohi rabi Icchak: „mąż boży Icchak” — czyli Izaak Luria.

${ }^{4}$ Sefer Ec Chajim.

** (Przyp. thum.) Tym znaczeniem w odniesieniu do sefirot posługuje się Sefer ha-Bahir [„,Księga Jasności”] (odwołująca się tu do biblijnej Księgi Psalmów) - pierwszy powstały tekst historycznej kabały. W akapicie 125 (angielskiego przekładu Aryeha Kaplana, The Bahir: Illumination, Weiser Books, York Beach, Maine 1990, s. 32; tekst ten odpowiada elektronicznej wersji zamieszczonej na stronie: http://www.hermetics.org/pdf/sacred/bahir.pdf [22.03.2015]) padają słowa: „Dlaczego nazywane są Sefirot? Ponieważ napisane jest (Psalm 19:2) «Niebiosa opowiadają (me-Saprim) chwałę Pana»" (thumaczenie z Księgi Psalmów za: Sefer Tehilim/Księga Psalmów, przeł. Izaak Cylkow, Warszawa 1884).

*** (Przyp. tłum.) Należy odnotować, że Sefer Jecira przez większość badaczy nie jest uważana za tekst kabalistyczny sensu stricto, powstała bowiem najpewniej w pierwszych wiekach n.e., a za początki kabały przyjmuje się wieki średnie (ok. XI-XII w.). Jest więc Sefer Jecira pomnikiem prekabalistycznym. Należy jednak oddać, że traktat ów był — poza Sefer ha-Zohar [„,Księgą Blasku"] — najpopularniejszą i najpilniej studiowaną przez kabalistów mistyczną księgą.
} 
Dziesięć sefir nicości. Dziesięć a nie dziewięć, dziesięć a nie jedenaście. Pojmij w mądrości i bądź mądry w pojmowaniu. Zgłębiaj je, badaj, ustal rzecz dokładnie i przywróć Stwórcy należne Mu miejsce. *

\section{Kabalistyczny opis Stworzenia}

Kabała charakteryzuje Boga jako Ein-Sof („bez końca”), bezgraniczną i niepoznawalną, nieskończoną sferę. Dekada sefirot jest układem Boskich mocy wewnątrz Bóstwa obejmującym prawa, poprzez które Bóg manifestuje nam Siebie, i stanowiącym narzędzie, za pomocą którego Bóg oddziałuje na Wszechświat.

Na początku Wszechświat nie istniał. Istnienie bytu poza Ein-Sof było niemożliwe, ponieważ stanowiłoby to ograniczenie Jego nieskończoności. Aby Wszechświat mógł zaistnieć, konieczne było dostąpienie przez Boga cimcum. Cimcum oznacza dosłownie „skurczenie się”, "* co Ari zrozumiał jako „wycofanie się". Mimo tego, że już Midrasz mówi o bycie Boga osiągającym cimcum, to tutaj Boski byt kurczy się i zagęszcza do punktu. Ari natomiast zinterpretował cimcum jako skurczenie i wycofanie się $z$ punktu. To Boskie wycofanie się umożliwiło zajście procesów stwórczych prowadzących do powstania wyodrębnionego bytu — Wszechświata — który mógł istnieć równolegle z Ein-Sof. ${ }^{5}$

\footnotetext{
Nota bene, Sefer Jecira z języka hebrajskiego oznacza „Księga Stworzenia” (w starożytnych rękopisach pojawia się także tytuł Sefer Otijot [,Księga Liter”] — jako że hebrajskie litery stanowią tutaj narzędzie kosmogoniczne). Księga należy do spekulatywnego kierunku ezoterycznej gałęzi religii mojżeszowej zwanej ma'ase bereszit (z hebr. dzieło stworzenia [początku]), jest pierwszym hebrajskim tekstem mistyczno-filozoficznym prezentującym systematyczną myśl teoretyczną, przybierającą tutaj postać rozważań nad aktem kreacji świata (kosmogonii i kosmologii), odnosząc się do pierwszego rozdziału biblijnej Księgi Rodzaju.

* (Przyp. thum.) Sefer Jecira, czyli Księga Stworzenia (wydanie dwujęzyczne), przekł., op. i kom. Wojciech Brojer, Jan Doktór, Bohdan Kos, TIKKUN, Warszawa 1995, s. 85. Por. drugie polskie thumaczenie: Księga Jecira, klucz kabały, przeł. Mariusz Prokopowicz, PICO, Warszawa 1994. nie".

** (Przyp. tłum.) Słowo cimcum występuje także w znaczeniu „ograniczenie”, „ogranicza-

${ }^{5}$ Sefer Ec Chajim, hejchal alef (adam kadmon), sza'ar alef, drusz iggulim we-joszer.
} 
Konsekwencją Boskiego wycofania się było powstanie przestrzeni, w którą wpłynął promień (kaw) Boskiego światła. Natura tego światła i ciąg procesów z nim związanych są przedmiotem literatury kabalistycznej. Dla naszej dyskusji istotne jest oddziaływanie światła na sefirot lub, ściślej biorąc, na naczynia (kelim) związane z każdą z dekady sefirot.

Naczynia trzech pierwszych sefirot zdołały przyjąć napływający w nie promień światła. Jednak światło, które uderzyło w siedem niższych sefirot, było zbyt silne i ich naczynia kolejno pękały i rozbijały się. Ta kabalistyczna koncepcja znana jest jako „rozbicie naczyń” (szewirat ha-kelim).

W przyszłości, w następstwie wypełniania przez ludzi Tory i micwot, siedem rozbitych sefirot będzie mogło odzyskać swoją doskonałość — proces ten nosi nazwę tikkun. Zanim jednak nastanie era tikkun, Wszechświat składać się będzie z trzech nienaruszonych i siedmiu rozbitych sefirot.

\section{Naukowy opis Stworzenia}

Gałąź nauki, która zajmuje się pochodzeniem Wszechświata, to kosmologia. " W każdej epoce i kulturze ludzie spoglądali na niebiosa, zadając sobie pytanie: skąd pochodzą ciała niebieskie - Słońce, Księżyc i gwiazdy? Stworzenia nie sposób było sobie wyobrazić, ponieważ nauka twierdziła, że coś nie może powstać z niczego. Dlatego naukowcy uznawali, że świat jest wieczny, sprytnie unikając przez to pytań o jego początek. Pojawiające się w Bereszit stwierdzenie, że Wszechświat został stworzony, stało się areną konfliktu pomiędzy nauką i Torą. Tak sprawy miały się przez wiele lat.

Ale sytuacja ta zmieniła się. Wiek dwudziesty był świadkiem niesłychanej eksplozji wiedzy naukowej. Ta eksplozja nigdzie nie okazała się bardziej gwałtowna niż właśnie w dziedzinie kosmologii. Astronomowie badali ciała niebieskie przez tysiąclecia, ale ograniczali się prawie wyłącznie do śledzenia torów, po jakich poruszają się gwiazdy, planety i komety, oraz ustalania ich struktury, widma i innych właściwości. Pochodzenie ciał niebieskich pozostawało całkowitą tajemnicą. Znaczny rozwój kosmologii na przestrzeni ostatnich kilkudzie-

\footnotetext{
* (Przyp. thum.) Ściślej biorąc, to kosmogonia. Kosmologia traktuje nie tylko o tym, jak Wszechświat powstał, ale i o tym, jaki jest.
} 
sięciu lat umożliwił naukowcom skonstruowanie po raz pierwszy spójnej historii początków Wszechświata. Dziś przytłaczająca liczba danych naukowych potwierdza kosmologiczną teorię Wielkiego Wybuchu. ${ }^{6}$

Oto ocena obecnego statusu naukowego teorii Wielkiego Wybuchu: „Teoria Wielkiego Wybuchu miewa się ostatnio wyjątkowo dobrze". ${ }^{7}$ Podobne poglądy wyraził w 1999 roku kosmolog Brian Greene z Columbia University:

Współczesna teoria początków kosmosu [głosi], że Wszechświat wybuchł w efekcie potężnego zdarzenia energetycznego [...] teoria stworzenia, która mówi o Wielkim Wybuchu, nazywana jest modelem standardowym w kosmologii. ${ }^{8}$

Najważniejszym twierdzeniem teorii Wielkiego Wybuchu jest, że Wszechświat dosłownie zostat stworzony. Warto przytoczyć tu słowa kilku czołowych światowych autorytetów.

Laureat Nagrody Nobla Paul Dirac, główny twórca dwudziestowiecznej fizyki, pisze: „Wydaje się pewne, że był określony czas stworzenia”. ${ }^{9}$ Wiodący

\footnotetext{
${ }^{6}$ Istnieją cztery najważniejsze rodzaje takich danych: 1. Odkrycie, że Wszechświat wypełniają pozostałości pierwotnej kuli świetlnej; 2. Stosunek wodoru do helu we Wszechświecie; 3. Ekspansja galaktyk; 4. Odkrycie, na podstawie pomiarów dokonanych w 1990 roku przez sztucznego satelitę COBE oraz dodatkowych pomiarów tego promieniowania wykonanych przez sztucznego satelitę MAP wystrzelonego w kosmos w 2001 roku, że promieniowanie reliktowe ma identyczne widmo, jak ciało doskonale czarne.

${ }^{7}$ George Musser, „Cztery klucze do kosmosu”, Świat Nauki 2004, nr 3 (151), s. 22 [22-23].

${ }^{8}$ Brian Greene, The Elegant Universe: Superstrings, Hidden Dimensions, and the Quest for the Ultimate Theory, W.W. Norton, London 1999, s. 345-346.

(Przyp. tłum.) Przekład własny na podstawie cytatu przytaczanego przez Aviezera. W polskim przekładzie (ani pierwszego, ani drugiego wydania) cytowany fragment nie występuje, pojawiają się natomiast słowa: „Zgodnie z przyjętą obecnie naukową teorią stworzenia, na samym początku istnienia Wszechświata panowały w nim niezwykłe warunki - olbrzymia energia, temperatura i gęstość. [...] Wkrótce omówimy najświeższe odkrycia, ale najpierw przedstawimy teorię kosmologiczną sprzed powstania teorii strun, nazywaną często modelem standardowym w kosmologii" (Brian Greene, Piękno Wszechświata. Superstruny, ukryte wymiary i poszukiwania teorii ostatecznej, przeł. Ewa L. Łokas i Bogumił Bieniok, Na Ścieżkach Nauki, Prószyński i Ska, Warszawa 2001, s. 339; wyd. 2 — Prószyński i S-ka, Warszawa 2006, s. 280).

${ }^{9}$ Paul A.M. Dirac, „,Recent Results in Cosmology”, Commentarii 1972, vol. 2, no. 11, s. 15.
} 
kosmolog Stephen Hawking wskazuje: „Stworzenie leży poza zakresem znanych nam dziś praw fizyki”. ${ }^{10}$

Co mają na myśli kosmologowie używający pojęcia „stworzenie”? Co dokładnie zostało stworzone? Naukowcy odkryli, że Wszechświat miał swój początek wraz z nagłym pojawieniem się ogromnej kuli światła zwanej „pierwotną kulą świetlną". * Ta „eksplozja światła” została przez brytyjskiego astrofizyka Freda Hoyle'a nazwana „Wielkim Wybuchem”. ${ }^{11}$ Pozostałości owej pierwotnej świetlnej kuli po raz pierwszy wykryło w 1965 roku dwóch amerykańskich fizyków, Arno Penzias i Robert Wilson, którzy za swoje odkrycie zostali uhonorowani Nagrodą Nobla w dziedzinie fizyki.

\section{Kabala a nauka}

Podsumujmy teraz trzy główne punkty opisu Stworzenia według kabały: 1. Wszechświat zaistniał na mocy aktu stworzenia; 2. Boskie światło odegrało kluczową rolę w stworzeniu; 3. Istnieją trzy nienaruszone sefirot i siedem sefirot rozbitych. Naszym obecnym zadaniem jest odniesienie tych trzech punktów kabalistycznego opisu Stworzenia do naukowej teorii stworzenia Wszechświata.

Pierwszy punkt kabalistycznego opisu dotyczy pewnego zdarzenia - to jest Stworzenia. Odpowiednio kosmologiczna teoria Wielkiego Wybuchu głosi, że Wszechświat rzeczywiście został stworzony. Praktycznie niemożliwe jest dziś przeprowadzenie poważnej dyskusji o kosmologii bez przyjęcia fundamentalnej tezy o stworzeniu Wszechświata.

Drugi i trzeci punkt kabalistycznego opisu dotyczą bytów - Boskiego światha i dziesięciu sefirot. Jak powiedziano wcześniej, zgodnie z doktryną kabały

\footnotetext{
${ }^{10}$ Stephen Hawking, The Large Scale Structure of Space-Time, Cambridge University Press, Cambridge, United Kingdom 1973, s. 364.

* (Przyp. thum.) Cytowany wcześniej Brian Greene mówi o „morzu pierwotnych fotonów” (Greene, Piękno Wszechświata..., wyd. 2, s. 282-283).

${ }^{11}$ Naukowcy używają często terminu ,promieniowanie elektromagnetyczne”, który oznacza tyle, co światło. Aby uniknąć terminologii technicznej, posługujemy się słowem światło.

** (Przyp. thum.) Chodzi tu o odkrycie kosmicznego mikrofalowego promieniowania tha (promieniowania reliktowego).
} 
każdy byt górnego świata duchowego zstępuje, przyjmując odpowiednią formę, do sfery fizycznej świata dolnego. Oznacza to, że w świecie dolnym można odnaleźć fizyczne odpowiedniki Boskiego światła i dziesięciu sefirot.

Fizycznym odpowiednikiem Boskiego światła z nauczania kabały jest pierwotne światło Wielkiego Wybuchu. Standardowa teoria kosmologiczna głosi, że tym, co zostało stworzone na początku czasu, była ogromna świetlna kula, określana powszechnie jako Wielki Wybuch — stąd nazwa teorii. Za pomocą odpowiedniej aparatury również dziś można zaobserwować pozostałości tego pierwotnego światła sięgającego samych początków czasu.

Problem leży w trzecim punkcie kabalistycznego opisu Stworzenia. Co bowiem mogłoby być fizycznym odpowiednikiem dziesięciu sefirot? Ponieważ sefirot opisywane są często jako „wymiary Boga”, przeto proponujemy, aby fizycznym odpowiednikiem sefirot $\mathrm{w}$ świecie dolnym uczynić wymiary przestrzenne Wszechświata. Zgodnie $\mathrm{z}$ tą sugestią trzy nienaruszone sefirot odpowiadają trzem znanym wymiarom przestrzeni: wschód-zachód, północ-południe, góra-dół.

Doprowadza nas to do sedna problemu: sumą sefirot jest liczba dziesięć. Czy można $\mathrm{w}$ jakimś sensie mówić o dziesięciowymiarowym Wszechświecie? I co rozumie się przez rozbite sefirot? Czy istnieje coś takiego jak rozbity wymiar?

Na powyższe pytania odpowiada teoria strun, ${ }^{12}$ współczesny naukowy opis Wszechświata. Zgodnie z teorią strun Wszechświat składa się z dziesięciu wymiarów przestrzennych. Odkrycie to stało się źródłem wielkich emocji. Na okładce jednego $\mathrm{z}$ numerów pewnego czasopisma naukowego pojawiły się następujące słowa: „Teoria strun i czasoprzestrzeń z jedenastoma wymiarami”. ${ }^{13} 14$

\footnotetext{
${ }^{12} \mathrm{~W}$ toku swojego rozwoju teoria strun przeszła ewolucję w nomenklaturze. Nazywana była teorią superstrun, teorią bran i M-teorią — to ostatnie określenie pozostaje popularne pośród specjalistów. Tutaj będziemy stosować szerzej znaną nazwę „teoria strun”, jakkolwiek przytaczać będziemy najnowsze ustalenia M-teorii.

${ }^{13}$ „Questions and Answers”, Scientific American November 2003: okładka przednia.

(Przyp. tłum.) W polskojęzycznym wydaniu tego czasopisma, czyli Świecie Nauki, w numerze grudniowym 2003, na okładce widnieją jedynie słowa: „Struny i nowa czasoprzestrzeń”.
} 
Na jedenaście wymiarów czasoprzestrzeni, o których mówi teoria strun, składają się jeden wymiar czasowy i dziesięć wymiarów przestrzennych.

Trzy z dziesięciu wymiarów przestrzennych to zwykłe wymiary wspomniane wcześniej (góra-dół, wschód-zachód, północ-południe), podczas gdy pozostałych siedem wymiarów zostało „zwiniętych” (w języku teorii strun) i, w rezultacie, nie są one bezpośrednio dostępne naszym zmysłom. $\mathrm{Z}$ tego powodu myślano wcześniej, że zamieszkujemy Wszechświat składający się wyłącznie $\mathrm{z}$ trzech wymiarów.

Znaczenie tych zdumiewających twierdzeń naukowych leży w tym, że wskazują one na powiązania pomiędzy nauką (teorią strun) a kabałą. Można bowiem dopatrzyć się fizycznego odpowiednika siedmiu rozbitych sefirot kabały w siedmiu zwiniętych wymiarach postulowanych przez teorię strun.

\section{Grawitacja}

Aby zrozumieć, dlaczego naukowcy mówią o Wszechświecie dziesięciowymiarowym, poznać należy teorię grawitacji. Przez lata przeszła ona szereg ważnych zmian, które teraz opiszemy.

1. W 1687 roku Sir Izaak Newton zaproponował pierwszą teorię grawitacji. W dziele Principia, najważniejszej kiedykolwiek napisanej książce naukowej, Newton wprowadził ideę, że każde dwa obiekty we Wszechświecie przyciągają się wzajemnie siłą, zwaną grawitacją, której wielkość zależy od odległości pomiędzy tymi obiektami. Założenie to pozwoliło Newtonowi wyjaśnić ruch planet, ale też wiele innych zjawisk, na przykład pływy.

Grawitacja jest jednym z czterech oddziaływań w przyrodzie. Pozostałe to dwa oddziaływania jądrowe (działające wewnątrz jądra atomu) oraz oddziaływanie elektryczne (lub, ściślej biorąc, oddziaływanie elektromagnetyczne, jako że elektryczność i magnetyzm są dwoma aspektami tego samego oddziaływania).

\footnotetext{
${ }^{14}$ Einsteinowska teoria szczególnej względności głosi, że przestrzeń i czas są złączone, toteż mówi się o czasoprzestrzeni. Ograniczymy tymczasem naszą dyskusję do wymiarów przestrzennych. Koncepcja czasu w kabale jest zagadnieniem wymagającym odrębnego opracowania.
} 
2. W 1905 roku Albert Einstein wystąpił z propozycją szczególnej teorii względności, ustanawiając związek pomiędzy materią $(M)$ i energią $(E)$ poprzez wprowadzenie słynnego wzoru $E=M c^{2}$, gdzie litera $c$ oznacza prędkość światła. Szczególna teoria względności potwierdzana była niezliczoną liczbę razy i jest jedną z fundamentalnych zasad nauki.

Każda teoria naukowa musi być zgodna ze szczególną teorią względności. Teorie oddziaływań jądrowych i oddziaływania elektrycznego okazały się zgodne ze szczególną teorią względności, ale Newtonowskiej teorii grawitacji nie udało się uzgodnić z zasadami tej teorii. Dziesięć lat zajęło Einsteinowi sformułowanie nowej teorii grawitacji, która była zgodna ze szczególną teorią względności. W 1916 roku Einstein ogłosił swoją teorię grawitacji, nazwaną przezeń „ogólną teorią względności”, a uważaną przez wiodących naukowców za „najpiękniejszą ze wszystkich istniejących teorii fizycznych”. ${ }^{15}$

3. Najbardziej zadziwiającym wnioskiem wypływającym $z$ teorii Einsteina jest, że grawitacja nie jest siłą, tylko „zakrzywieniem przestrzeni”. ${ }^{16}$ Przyciąganie grawitacyjne pomiędzy dwoma obiektami nie jest skutkiem przyciągania jednego obiektu przez drugi - jak to jest w wypadku oddziaływania elektrycznego pomiędzy dwoma ładunkami elektrycznymi. Grawitacja działa w sposób następujący: pierwszy obiekt „zakrzywia” przestrzeń wokół siebie, wywołując w ten sposób ruch drugiego obiektu. Jako że nie jesteśmy w stanie ujrzeć zakrzywienia przestrzeni, wygląda to, jak gdyby dwa obiekty przyciągały się za pomocą siły.

Koncepcję tę najlepiej obrazuje ilustracja na Rysunku 1. U góry rysunku widać rozwiniętą gumową płaszczyznę, na której nieruchomo leży mała kulka. Dolna część rysunku pokazuje, co się dzieje, gdy na gumowej płaszczyźnie umieszczona zostanie duża kulka. Oddziaływanie dużej kulki polega na zakrzywieniu gumowej płaszczyzny, przy czym im bliżej dużej kulki, tym zakrzywienie jest większe, a im od niej dalej — mniejsze.

\footnotetext{
${ }^{15}$ Lev Landau and Eliav Lifshitz, The Classical Theory Of Fields, 2d ed., Oxford 1962, s. 260.

${ }^{16}$ Einsteinowska teoria grawitacji implikuje również zakrzywienie czasu (nazwane dylatacją czasu), jako że czas jest połączony z przestrzenią. Tutaj jednak nie będziemy omawiać zagadnienia czasu.
} 
W wyniku zakrzywienia gumowej płaszczyzny mała kulka zaczyna poruszać się w kierunku miejsca największego zakrzywienia (czyli tam, gdzie znajduje się duża kulka). Toteż mała kulka porusza się $w$ kierunku dużej kulki. Jednak pomiędzy kulkami nie istnieje żadna siła przyciagania. Przyczyną ruchu małej kulki jest zakrzywienie gumowej płaszczyzny, spowodowane z kolei przez dużą kulkę.

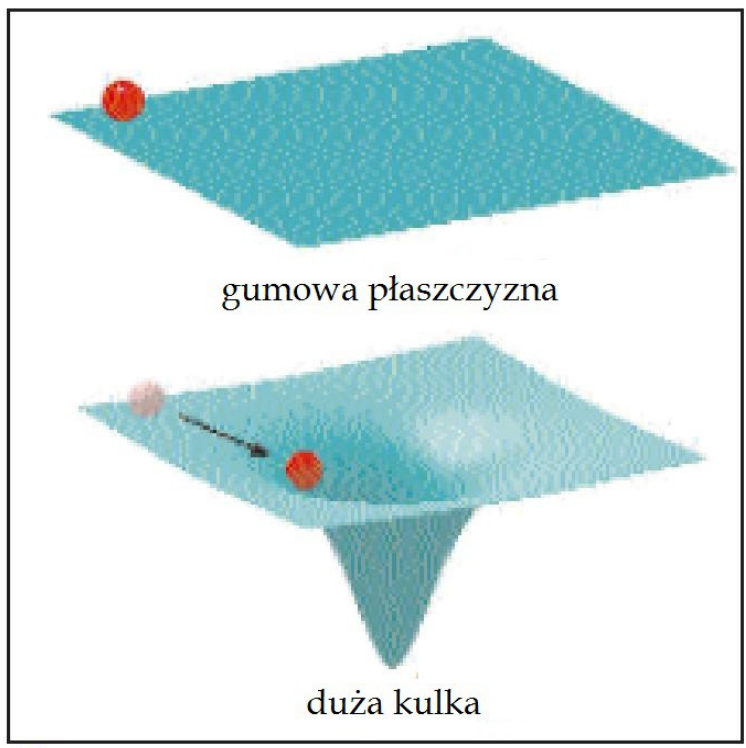

Rysunek 1

Gumowa płaszczyzna reprezentuje przestrzeń, której „zakrzywienie” jest dla nas niewidoczne. Widzimy jedynie małą kulkę poruszającą się w kierunku dużej kulki. Dlatego właśnie Newton założył, że pomiędzy każdą parą mas istnieje siła przyciągania (grawitacja). Einstein jednakże wykazał, że grawitacja nie jest siłą i że właściwym określeniem grawitacji jest zakrzywienie przestrzeni.

Teorie grawitacji wysunięte przez Newtona i Einsteina są diametralnie różne. W praktyce przewidywania tych dwóch teorii są jednak bardzo podobne. Przewidywania te są $\mathrm{w}$ istocie tak mocno porównywalne, że przez dwa stulecia nikt nie poddał w wątpliwość teorii Newtona. Wszelako zawsze, gdy te dwie 
teorie różnią się nieco przewidywaniami, to teoria Einsteina okazuje się zgodna ze szczegółowymi obserwacjami. Z tego powodu Einsteinowska teoria grawitacji zaakceptowana została przez ogół naukowców.

Podsumowując, grawitacja nie jest siłą, lecz zakrzywieniem przestrzeni. Dlatego też grawitacja jest czymś całkowicie innym niż pozostałe trzy oddziaływania występujące w przyrodzie. Ujrzymy wkrótce znaczenie tego faktu.

4. Lata dwudzieste dwudziestego wieku to okres rozwoju teorii kwantów. Rewolucyjność teorii kwantów polega na przyjęciu tezy, że Wszechświat jest probabilistyczny, a nie - jak sądzono wcześniej — deterministyczny. Teoria kwantów zakłada, że już w zasadzie niemożliwe jest przewidzenie, co wydarzy się w przyszłości. Można jedynie przewidzieć, co może się wydarzyć z różnym prawdopodobieństwem. (Najlepszym przedstawieniem teorii kwantów zrozumiałym dla laika jest książka laureata Nagrody Nobla Richarda P. Feynmana, QED: The Strange Theory of Light and Matter, New Jersey 1998. *)

Teoria kwantów została potwierdzona przez tysiące eksperymentów i ustanowiono ją podstawową zasadą nauki. Każda poprawnie skonstruowana teoria naukowa musi być zgodna z teorią kwantów. Feynman otrzymał Nagrodę Nobla za opracowanie procedury nazwanej „renormalizacją”, która uzgadnia teorię oddziaływania elektrycznego z teorią kwantów. Procedura Feynmana sprawdza się także w wypadku oddziaływań jądrowych. Kiedy jednak naukowcy zastosowali procedurę Feynmana do Einsteinowskiej teorii grawitacji, wyniki okazały się nonsensowne. ${ }^{17}$ Porażkę tę uzasadniono tym, że grawitacja nie jest siłą, tylko zakrzywieniem przestrzeni. To jest właśnie powód, dla którego Einsteinowska teoria grawitacji pozostaje niezgodna $\mathrm{z}$ teorią kwantów.

Jest to $\mathrm{w}$ istocie bardzo poważny problem. Zarówno teoria kwantów, jak i Einsteinowska teoria grawitacji z pewnością są prawidłowe. Dlaczego więc nie sposób pogodzić ze sobą dwóch poprawnych teorii mówiących o przyrodzie? Dlaczego niemożliwe jest sformułowanie spójnej teorii „kwantowej grawitacji”?

\footnotetext{
* (Przyp. thum.) Polskie wydanie: Richard Feynman, QED. Osobliwa teoria światla i materii, przeł. Helena Białkowska, Państwowy Instytut Wydawniczy, Warszawa 1992.

${ }^{17}$ Wartość obliczona dla wielu mierzalnych wielkości okazała się nieskończona. Poza tym teoria ta posiadała wewnętrzne niespójności.
} 
5. Sprzeczność widoczną pomiędzy teorią kwantów a Einsteinowską teorią grawitacji rozwiązuje teoria strun. (Znakomite popularnonaukowe przedstawienie teorii strun to praca propagatora tej teorii Briana GreENE'A, The Elegant Universe.... ")

Teoria strun jest nową konstrukcją pojęciową używaną do opisu fizycznego Wszechświata. Zgodnie z wcześniejszą koncepcją elementarnymi jednostkami Wszechświata są cząstki - elektron, kwark, foton i tak dalej. Wedle teorii strun podstawowymi jednostkami Wszechświata są maleńkie struny. Struny te mogą wibrować (jak struna skrzypiec), a energia wibracji przejawia się jako cząstka na mocy ustalonej przez Einsteina zależności między energią i masą $\left(E=M c^{2}\right)$.

Jeśli zastosujemy teorię strun do trójwymiarowego Wszechświata, nic nam to nie da. W ramach trzech wymiarów teoria strun nie potrafi dostarczyć teorii kwantowej grawitacji. Co więcej, nie jest w stanie tego zrobić dla żadnej liczby wymiarów przestrzennych mniejszej niż dziesięć — ale dla dziesięciowymiarowego Wszechświata już tak. Innymi słowy, jeśli nasz Wszechświat składa się $\mathrm{z}$ dziesięciu wymiarów przestrzennych (i jednego wymiaru czasowego), to zgodnie z teorią strun Einsteinowska teoria grawitacji okazuje się zgodna z teorią kwantów. To ważne odkrycie sprawiło, że teorię strun uznaje się za wiodącą kandydatkę do otrzymania czegoś, co często nazywane jest Teorią Wszystkiego.

Krótko mówiąc, naukowcy odkryli, że Einsteinowska teoria grawitacji może być zgodna z teorią kwantów tylko jeśli Wszechświat składa się z dziesięciu wymiarów przestrzennych. ${ }^{18}$ Ponieważ te dwie teorie musza być ze sobą zgodne, przeto Wszechświat musi być dziesięciowymiarowy.

6. W tym miejscu pojawiają się następujące pytania: w jaki sposób można pogodzić teorię strun (model dziesięciowymiarowego Wszechświata) z naszym codziennym doświadczeniem (model trójwymiarowego Wszechświata)? Jakie znaczenie ma siedem brakujących wymiarów? Dlaczego ich nie doświadczamy?

\footnotetext{
* (Przyp. tłum.) Polskie wydanie: Greene, Piękno Wszechświata....

${ }^{18}$ Teoria strun dostarcza ponadto spójnej teorii kwantowej grawitacji dla Wszechświata składającego się z dwudziestu sześciu wymiarów, a także dla Wszechświata składającego się z jeszcze większej liczby wymiarów. Naukowcy skupiają się jednak na najmniejszej liczbie wymiarów (dziesięć), dla których istnieje spójna teoria kwantowej grawitacji.
} 
Teoria strun udziela odpowiedzi. Siedem brakujących wymiarów zwiniętych zostało do rozmiarów tak małych, że niemożliwe jest doświadczenie ich. Podczas gdy każdy z trzech zwykłych wymiarów rozciąga się do nieskończoności, pozostałe siedem wymiarów rozciągają się tylko na bardzo niewielką skalę. Jak wyjaśnia Gabriele Veneziano, twórca teorii strun:

elektrony to przypuszczalnie struny, których końce poruszają się swobodnie w trzech z dziesięciu wymiarów przestrzennych, lecz są umiejscowione w pozostałych siedmiu. [...] Owa częściowa tylko mobilność elektronów i innych cząstek wyjaśnia, dlaczego nie postrzegamy przestrzeni $\mathrm{w}$ jej pełnym, 10 -wymiarowym bogactwie. ${ }^{19}$

Koncepcja zwiniętego wymiaru została przedstawiona na Rysunku 2. Jego górna część ukazuje rurę, ${ }^{*}$ której trzema wymiarami są jej długość oraz pole przekroju poprzecznego, dolna zaś obrazuje pole przekroju poprzecznego pomniejszone $\mathrm{w}$ stopniu umożliwiającym zwężenie rury do postaci nitki. Wraz $\mathrm{z}$ dalszym zmniejszaniem pola przekroju poprzecznego te dwa wymiary stają się obserwowalne z trudnością, aż w końcu niemożliwe jest ich zaobserwowanie.

Wedhug teorii strun zwinięty wymiar jest wielkości jednej miliardowej miliardowej miliardowej promienia atomu (wielkość ta zwana jest, na cześć laureata Nagrody Nobla Maxa Plancka, „długością Plancka”). Tak małej jednostki długości nie sposób wykryć za pomocą jakiegokolwiek instrumentu pomiarowego. To właśnie oznacza „Zwinięty wymiar” — wymiar, który istnieje, ale jest dalece zbyt mały, aby go zmierzyć. Pomimo tego, że zwiniętych wymiarów nie sposób zmierzyć bezpośrednio, wywierają one znaczące pośrednie skutki na Wszechświat.

Jednym z takich pośrednich skutków jest to, że idea zwiniętych wymiarów prowadzi do spójnej teorii kwantowej grawitacji. ${ }^{20}$

\footnotetext{
${ }^{19}$ Gabriele Veneziano, „Mit początku czasu”, Świat Nauki 2004, nr 6 (154), s. 55 [48-57].

* (Przyp. tłum.) Decyduję się używać takiego właśnie polskiego odpowiednika słowa pipe. Skłoniło mnie do tego występowanie słowa „rura” w polskim przekładzie książki Lawrence’a Kushnera (Lawrence KuSHNER, Miód ze skały. Wizje odnowy mistyki żydowskiej, przeł. Zdzisław Wiese, Dom Wydawniczy REBIS, Poznań 1994, s. 76), aplikowanego de facto do rozważań nad czasoprzestrzenią i grawitacją, a z drugiej strony rozważań nad żydowskimi ideami mistycznymi.

${ }^{20}$ Inne ważne rozstrzygnięcie koncepcji zwiniętych wymiarów dotyczy siły oddziaływań w przyrodzie. Przy normalnych (niskich) energiach siła oddziaływań rozciąga się od bardzo silne-
} 


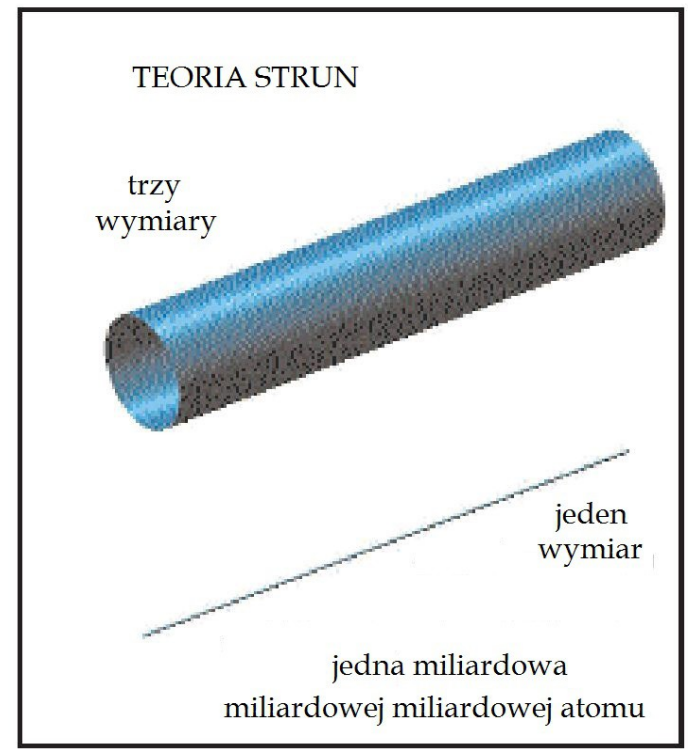

Rysunek 2

\section{Kabala, nauka i Stworzenie - podsumowanie}

Teoria strun jest współczesną konstrukcją naukową pozwalająca zrozumieć Wszechświat. Jednym z najdonioślejszych odkryć teorii strun jest to, że zamieszkujemy Wszechświat dziesięciowymiarowy. Z tych dziesięciu wymiarów trzy są znanymi nam wymiarami przestrzennymi, podczas gdy pozostałych siedem zwija się w procesie Stworzenia, przez co „nie postrzegamy przestrzeni w jej pełnym, 10-wymiarowym bogactwie". ${ }^{21}$

Kabała, opisująca duchowy świat powyżej, mówi o dekadzie sefirot. Trzy $\mathrm{z}$ tych dziesięciu sefirot pozostają nienaruszone, a pozostałych siedem rozbitych

go oddziaływania jądrowego do bardzo słabego oddziaływania grawitacyjnego. Wykazano, że na określonym, bardzo wysokim poziomie energii, zwanym energią Planka, wszystkie oddziaływania w przyrodzie muszą mieć tę samą siłę. Obliczenia pokazują, że przewidywanie to jest trafne jedynie jeśli Wszechświat posiada dodatkowe zwinięte wymiary.

${ }^{21}$ Veneziano, ,Mit początku czasu...”, s. 55. 
zostaje w trakcie procesu Stworzenia. Dziesięciowymiarowy Wszechświat świata dolnego należy zidentyfikować jako fizyczny odpowiednik dziesięciu sefirot świata górnego. Podobnie, siedem zwiniętych wymiarów świata dolnego jest fizycznym odpowiednikiem siedmiu rozbitych sefirot świata górnego. Świat górny i świat dolny stanowią, odpowiednio, duchowy i fizyczny przejaw Wszechświata.

Świat górny radowat się i świat dolny świętowat, kiedy Tora nadana została na Górze Synaj (Jocrot ${ }^{*}$ na Szawuot, ${ }^{* *}$ Musaf ${ }^{* * *}$ na dzień pierwszy ${ }^{* * *}$ ).

Nathan Aviezer

\section{Kabbalah, Science and the Creation of the Universe}

\section{Summary}

This paper examines the problem of the creation of the universe from a Kabbalah (viz. Jewish mysticism's branch) point of view and asserts similarity of this account with one modern scientific hypothesis - namely, string theory. The correlation is put forward by highlighting the parallels between the assumed ten spatial dimensions of string theory and the ten sefirot of Kabbalah. The key role is played here by the kabbalistic (from the lurianic Kabbalah) concept of shevirat ha-kelim ("breaking of the vessels"). The author argues that the three upper, "intact" in the process of creation, sefirot (i.e. kelim) are the counterparts of the three perceived spatial dimensions (up-down, east-west, north-south), and the seven lower, "broken", sefirot (kelim) are the counterparts of the string theory's seven spatial dimensions compacted in the proccess of creation (hence not experienced by humans).

\footnotetext{
* (Przyp. thum.) Poetyckie wersety; także modlitewnik.

** (Przyp. tłum.) Żydowskie święto upamiętniające otrzymanie przez Mojżesza Tory na Synaju; zwane również „Świętem Tygodni”, „Pięćdziesiątnicą” oraz „Świętem Żniw” (pierwotnie było to święto rolnicze).

*** (Przyp. tłum.) Modlitwa żydów odmawiana w cotygodniowy szabat i w święta, nawiązująca do dodatkowych ofiar składanych przy tych okazjach. Składają się na nią Kadisz (najpopularniejsza modlitwa liturgii judaizmu; wyznanie monoteizmu), osiemnaście błogosławieństw Szmone Esre (powtarzanych), hymny oraz Aleinu LeSzabeach (modlitwa kończąca modły); por. Polski Słownik Judaistyczny, hasło „musaf”: http://www.jhi.pl/psj/musaf (12.11.2014).

**** (Przyp. thum.) W diasporze święto Szawout trwa dwa dni.
} 
Keywords: Kabbalah, sefirot, shevirat ha-kelim, string theory, spatial dimensions, cosmology, science, creation, Judaism.

Slowa kluczowe: kabała, sefirot, szewirat ha-kelim, teoria strun, wymiary przestrzenne, kosmologia, nauka, stworzenie, judaizm. 